\title{
Formulation of Emulsified Modification Bitumen from Industrial Wastes
}

\author{
Mohd Najib Razali*, Syarifah Nur Ezatie Mohd Isa, Noor Adilah Md Salehan, Musfafikri Musa, \\ Mohd Aizudin Abd Aziz, Abdurahman Hamid Nour, and Rosli Mohd Yunus
}

Faculty of Chemical and Natural Resources Engineering, Universiti Malaysia Pahang, Lebuhraya Tun Razak 26300, Gambang, Pahang, Malaysia

\author{
${ }^{*}$ Corresponding author: \\ tel: $+6012-3530738$ \\ email:najibrazali@ump.edu.my \\ Received: August 3, 2018 \\ Accepted: December 14, 2018 \\ DOI: $10.22146 / \mathrm{ijc} .40888$
}

\begin{abstract}
The aim of this research was to characterize and analyze the formulation of emulsified modification bitumen (EMB) as well as the industrial wastes used in the formulation. Bitumen being a non-renewable product with severe environmental issues arising lately led to the use of industrial wastes such as plastic and recycled base oil in this research. Physical characteristic studies were performed to analyze the decomposition temperature, boiling point, flash point, density, moisture content, element content in waste plastics, and flowability of bitumen emulsion. Eight ratios of modified bitumen were formulated and compared with the industrial grade bitumen. The modified bitumen with a penetration value of $103 \mathrm{~mm}$ and softening value at $49{ }^{\circ} \mathrm{C}$ was chosen for the emulsification process where three emulsifiers were added into the mixture of bitumen and water. These samples were compared with the industrial bitumen emulsion. From the analysis, the formulated emulsion was obtained from a mixture consists of $20 \%$ bitumen, $7 \%$ polymer, and $73 \%$ recycled base oil.
\end{abstract}

Keywords: bitumen; non-renewable; Emulsified Modified Bitumen (EMB); polyethylene; recycled base oil

\section{- INTRODUCTION}

Bitumen is a thermoplastic material widely used in roofing, waterproofing products, and road construction applications [1]. The current world bitumen consumption is estimated to be 102 million tons per year of which $85 \%$ is used as a binder for pavements, $10 \%$ for roofing applications, and the rest is used for other purposes [2]. Bitumen emulsion, on the other hand, is a mixture of bitumen, water, and emulsifier which was used to provide breaking of bitumen into smaller particles, allowing the dispersion of bitumen suspended in the liquid [3]. It is widely used in various surface treatment applications, including micro surfacing, slurry seal, and chip seals. These are recognized to be the most promising techniques among various preventive pavement maintenance treatments [4]. The global market size for bitumen is expected to surpass USD150 million by 2024 [5].

In Malaysia, the urge to solve the environmental issue is getting crucial. Rapid urbanization, industrialization, and increasing population have worsened the situation. In 2003, the average amount of MSW generated in Malaysia was $0.5-0.8 \mathrm{~kg} /$ person/day and it has increased to $1.7 \mathrm{~kg} /$ person/day in major cities [6]. A survey made by Kathirvale et al. [6] concluded that plastic is the second biggest contributor to wastes generated in Kuala Lumpur at around 11-26\% after food and organic waste at 30-54\%. Moreover, Environmental Protection Expenditure (EPE) 2014 was reported to the tune of RM2.244 billion with the manufacturing sector being the highest contributor to this EPE at RM1.619 billion [7]. Wastes such as polyethylene and recycled base oil can be used to formulate modified bitumen and essentially with the help of suitable emulsifier, can produce emulsified modification bitumen (EMB). The formulated EMB will be used for insulation and coating of a building.

The EMB formulated from wastes will help to decrease many environmentally threatening aspects such as lowering the energy consumption and level of $\mathrm{CO}_{2}$ emission to the environment during construction works [8]. Besides, bitumen emulsion presents a much 
lower viscosity and can be applied at a temperature as low as $80^{\circ} \mathrm{C}$. A conventional binder is sprayed at $160-200{ }^{\circ} \mathrm{C}$ so there is a much more additional risk of fire and explosion [9]. Since the beginning of the evolution in recycling technology, many studies involving EMB formulations and applications have been conducted and published. However, not much waste was used and limited in terms of its application. Carrera et al. [9] stated that using recycled polyethylene by up to $5 \mathrm{wt}$.\% improved the bitumen performance at high service temperatures of $60^{\circ} \mathrm{C}$. Carrera et al. [10] claimed that a higher content of polymer of $4 \mathrm{wt} . \%$ enhanced the resistance to permanent deformation at approximately $60{ }^{\circ} \mathrm{C}$ compared with the standard nonmodified bituminous emulsions. Cai et al. [11] reported the use of nonrecycled styrene-butadienestyrene (SBS) at 3-5 wt.\% by dissolving it first in toluene. Some properties improved such as thermal stability, adhesion property with aggregates, and better crack resistance compared with those of pure bitumen emulsion. The past research has been focusing on using one type of waste only and particularly for surface dressing application on road constructions. Besides, in this past few years, fungal and mold growth in the operation theatre in hospitals has become a major problem in the health sector [12]. It is produced when the vapor from the air conditioner units turns to liquid, and this wet condition leads to the growth of fungi on the wall. These pathogens can enter human bodies via inhalation, ingestion, and skin contact [13]. It can be life-threatening as it may affect the respiratory system of patients and contaminate the facilities used to treat the patients. So, it is important to produce waterproofing surface dressing known as EMB that can be used both for road construction and building surface dressing to prevent fungi contamination in health sector along with the aim to reduce wastes in Malaysia.

\section{- EXPERIMENTAL SECTION}

\section{Materials}

The bitumen grade $80 / 100$ supplied by industry has been used to mix with waste materials. Industrial bitumen emulsion used to compare between formulated bitumen emulsions was obtained from Selangor. High density polyethylene and polystyrene wastes having a melting point in the range of $125-148^{\circ} \mathrm{C}$ and moisture content range from 0.27 to $0.78 \%$ were from landfills. Three types of recycled base oil collected from Kemaman, Banting and Kuantan and the waste sludge collected in Kemaman.

\section{Procedure}

The modified bitumen was prepared by using an IKA C-MAG HS 7 mechanical stirrer consisting of a three blade stirrer. This device was operated at $500 \mathrm{rpm}$ for $3 \mathrm{~h}$ at a blending temperature of $180^{\circ} \mathrm{C}$. Then, HDPE polymer, recycled base oil, and bitumen were added at $80,60,40$, and 20 wt.\%. Next, bitumen emulsion was prepared by using the same device. Three different types of chemical emulsifier were then mixed with the modified bitumen at an operating temperature of $70^{\circ} \mathrm{C}$.

Sample analysis such as TGA was performed to determine the decompose temperature and the composition in a sample. This analysis measures the weight loss percentage of a test sample while heated at increasing $10{ }^{\circ} \mathrm{C} / \mathrm{min}$ until approximately $900{ }^{\circ} \mathrm{C}$ under inert gas $2.5 \mathrm{mg}$ pf test specimen is weighed and the loss in weight over specific temperature ranges provides an indication to the composition of the sample. This test was carried out using TA Instruments TGA Q-500.

Moisture content was performed using A\&D MS70 moisture analyzer by calculating the loss of weight on drying process employed to extract and measure the moisture in each sample. The sample is placed on a weighing pan located in the drying chamber then the drying chamber is closed. A standard drying temperature at $130{ }^{\circ} \mathrm{C}$ is entered. The instrument calculates the moisture content by comparing the initial weight of the sample to the weight after complete drying. The average complete time is below $5 \mathrm{~min}$ for solid sample and $1 \mathrm{~h}$ for sludge and emulsion.

X-ray Fluorescence (XRF) Spectrometry was carried out to determine the elemental composition of a sample. Each element present in one sample will produce a set of characteristic fluorescent $\mathrm{X}$-rays when it was excited by an external energy source which in turn categorizes the energy by its element. First the sample is filled in the specimen cup. The analysis is started after 
standard data is collected. The $\mathrm{X}$ radiation illuminates and excites the sample which in turn emits X-rays along with spectrum of wavelengths characteristic to atoms present in the sample. It is conducted using SEA XRF-2000R.

Penetration test was conducted using an automatic penetrometer to determine the bitumen grade. The apparatus used include penetrometer with a needle, timer, sample container, and thermometer. The melted sample was poured into the metal container and allowed to air cool for $45 \mathrm{~min}$. Then the sample was placed in the water bath at $25^{\circ} \mathrm{C}$ for about $1 \mathrm{~h}$. After that, the needle was assembled at the penetrator and was positioned until the tip contacts with the surface of the sample. The needle holder was then released for $5 \mathrm{sec}$. The reading shows the depth of the needle penetrating the sample indicating its grade.

Softening point test is used to measure the softening point of a bitumen sample including shouldered ring, ball cantering guide, ring holder and assembly, beaker, thermometer, and hotplate. The heated sample was poured into two shouldered rings and allow to a cool in ambient temperature for at least $30 \mathrm{~min}$. Then the rings were put in a water bath for $1 \mathrm{~h}$ at $25^{\circ} \mathrm{C}$ and once cooled, the sample was immersed in the bath and placed in a freezer at $15^{\circ} \mathrm{C}$ for $45 \mathrm{~min}$. After that, the apparatus with rings, ball, and thermometer in the bath was assembled. While the bath was heated from below by a hotplate, the temperature of the bath was recorded every minute until the sample softens and slightly touches the bottom of the ring apparatus.

Parallel plate geometry in dynamic shear rheometer TA Instruments Ares-G2 was used with a $5 \mathrm{~mm}$ diameter mold and $1 \mathrm{~mm}$ binder gap. Temperature sweep testing was performed in oscillatory mode at a fixed frequency of
$1.6 \mathrm{~Hz}$ and at temperatures varying from $30-78{ }^{\circ} \mathrm{C}$. From these, complex modulus (G”) was determined. In temperature sweep testing the amplitude and frequency were kept constant while manipulating the temperature. First, the sample was heated and poured on the test plates. The initial, final temperature and ramp of the $5 \mathrm{~s}$ are entered. Then the test is started after the desired initial temperature is achieved at $+0.1^{\circ} \mathrm{C}$.

\section{- RESULTS AND DISCUSSION}

\section{Raw Material Characterization}

Table 1 summarizes all analysis involved in which melting point value was obtained from differential scanning calorimeter and residue of plastic was by thermogravimetric analysis. In order to formulate bitumen, the oil needs to have a high flash point as this experiment is conducted at a maximum temperature of $180^{\circ} \mathrm{C}$; and the oil was used as the medium for the polymer to melt [14]. Base oil 3 is chosen because it has a stable supplier besides of its high temperature. Also, to compare in term of density, a highly dense base oil 3 is chosen as it easily tolerates with the polymer in the mixture. Amongst the three polymeric material, High Density Polyethylene (HDPE) 1 sample has the least moisture content of $0.266 \%$ followed by HDPE 2 sample at $0.389 \%$ and polystyrene sample at $0.757 \%$. Furthermore, the melting point of each sample needs to be determined so that the method developed for this work will ensure all material used is melted accordingly based on the temperature. To compare the material in term of residue, HDPE 1 has the least residue of $0.1026 \%$ while HDPE 2 has the highest residue at $2.606 \%$. It is easier for

Table 1. Summary of analysis done on different raw materials

\begin{tabular}{lccccc}
\hline Sample & $\begin{array}{c}\text { Flash Point } \\
\left({ }^{\circ} \mathrm{C}\right)\end{array}$ & $\begin{array}{c}\text { Density } \\
\left(\mathrm{kg} / \mathrm{m}^{3}\right)\end{array}$ & $\begin{array}{c}\text { Moisture } \\
\text { Content }(\%)\end{array}$ & $\begin{array}{c}\text { Melting } \\
\text { Point }(\%)\end{array}$ & $\begin{array}{c}\text { Residue } \\
(\mathrm{mg})\end{array}$ \\
\hline Base oil 1 & 132.5 & 0.9304 & 1.019 & - & - \\
Base oil 2 & 20.0 & 0.8070 & 0.504 & - & - \\
Base oil 3 & 65.0 & 0.8720 & 0.311 & - & - \\
Sludge & 145.5 & 1.1831 & 14.479 & - & - \\
HDPE 1 & - & - & 0.266 & 125.72 & 0.1026 \\
HDPE 2 & - & - & 0.389 & 123.75 & 2.6060 \\
Polystyrene & - & - & 0.757 & 147.79 & 0.1200 \\
\hline
\end{tabular}

Mohd Najib Razali et al. 
a material containing less amount of filler to undergo depolymerization process while being heated and mixed with the bitumen. So, base oil 3 and HDPE 1 was chosen as the raw materials for bitumen formulation.

\section{X-Ray Fluorescence (XRF)}

Elements such as chromium, calcium, tin, and sulfur are added to the polymers as fillers, stabilizers and pigments. These elements are used in order to improve the durability and flexibility of polymer but often it does not chemically bond with molecules of plastic rather than only to create a suspension in plastic thus may dislodge from plastic matrix over time [15]. Table 2 depicts the highest element in HDPE 1, HDPE 2 and polystyrene are $\mathrm{Ti}$ at $88.46 \%, \mathrm{P}$ at $44.16 \%$ and $\mathrm{Ca}$ at $59.71 \%$ respectively. The same elements exist in the three plastics are C, P, S, $\mathrm{Ca}$ and $\mathrm{Fe}$ in which HDPE 2 contained the highest concentration of $\mathrm{P}$ whereas polystyrene contained the highest amount of $\mathrm{Ca}$. Besides that, polystyrene has four extra elements namely $\mathrm{K}, \mathrm{Cu}, \mathrm{Mo}$, and $\mathrm{Al}$. It is because polystyrene is a different type of plastic compared to HDPE 1 and HDPE 2 as both of it came from the same polymer group. The extra elements exist in polystyrene compared to the other two plastics may be caused by their different applications. Roads and Maritime Services [16] and Munera and Ossa [17] stated that polymer-modified bitumen grades only consist of elastomeric and plastomeric plastics such as rubber, polyethylene, styrene-butadiene-styrene, and ethylene vinyl acetate. The extra elements exist in polystyrene are expected to not contribute positive influence in bitumen properties.

\section{Characterization Formulation of Modified Bitumen}

Table 3 shows eight modified bitumen formulation in different ratios of bitumen, HDPE and recycled base oil. The samples were then analyzed using standard bitumen test which is penetration and softening point test also thermogravimetric analysis following American Standard for Testing and Materials (ASTM) to compare the formulated bitumen with industrial grade bitumen.

\section{Penetration Test (ASTM D5)}

Bitumen grade is classified based on its penetration value. This value will determine its suitability for every application. In road construction, lower penetration grades were chosen in high temperature regions to prevent grease softening while higher penetration grades were used in colder regions to limit the cracking deformation [18]. For bitumen emulsion purposes, the grade of bitumen will affect its setting time when applied on a surface. The rapid setting is used for surface dressing, the medium setting is used for patch repairs work, and slow setting type of emulsion is used during

Table 2. XRF measurements for elements of three plastics (as percentage)

\begin{tabular}{llccc}
\hline \multirow{2}{*}{ No } & \multirow{2}{*}{ Elements } & \multicolumn{3}{c}{ Concentration (\%) } \\
\cline { 3 - 5 } & & HDPE 1 & HDPE 2 & Polystyrene \\
\hline 1 & $\mathrm{C}$ & 4.879 & 0.114 & 1.18 \\
2 & $\mathrm{P}$ & 2.34 & 7.16 & 2.25 \\
3 & $\mathrm{~S}$ & 1.32 & 20.29 & 59.71 \\
4 & $\mathrm{Ca}$ & 0.37 & 2.88 & 5.82 \\
5 & $\mathrm{Fe}$ & - & 5.61 & 2.59 \\
6 & $\mathrm{Cl}$ & 88.46 & - & 1.09 \\
7 & $\mathrm{Ti}$ & 2.16 & - & 9.30 \\
8 & $\mathrm{Si}$ & 0.41 & - & 1.05 \\
9 & $\mathrm{Zn}$ & - & 1.71 & - \\
10 & $\mathrm{Pd}$ & - & - & 0.98 \\
11 & $\mathrm{~K}$ & - & - & 0.57 \\
12 & $\mathrm{Cu}$ & - & - & 0.37 \\
13 & $\mathrm{Mo}$ & - & - & 2.42 \\
14 & $\mathrm{Al}$ & & & \\
\hline
\end{tabular}

Mohd Najib Razali et al. 
Table 3. The ratio of modified bitumen formulation (of $220 \mathrm{~g}$ )

\begin{tabular}{lcccccccc}
\hline Ratio weight (wt.\%) & $8: 0.7: 1.3$ & $8: 0.5: 1.5$ & $6: 0.7: 3.8$ & $6: 0.5: 3.5$ & $4: 0.7: 5.3$ & $4: 0.5: 5.5$ & $2: 0.7: 7.3$ & $2: 0.5: 7.5$ \\
\hline Sample code & $\mathrm{A}$ & $\mathrm{B}$ & $\mathrm{C}$ & $\mathrm{D}$ & $\mathrm{E}$ & $\mathrm{F}$ & $\mathrm{G}$ & $\mathrm{H}$ \\
Bitumen & 176.0 & 176.0 & 132.0 & 132.0 & 88.0 & 88.0 & 44.0 & 44.0 \\
HDPE & 15.4 & 11.0 & 33.0 & 22.0 & 15.4 & 11.0 & 15.4 & 11.0 \\
Recycled base oil & 28.6 & 33.0 & 55.0 & 66.0 & 116.6 & 121.0 & 160.6 & 165.0 \\
\hline
\end{tabular}

rainy season. Based on the result shown in Fig. 1, the lowest and the hardest grade of bitumen was at ratio 8:0.7:1.3 (A) which contained 80 wt.\% in bitumen, 7 wt.\% in HDPE and 13 wt.\% in recycled base oil whereas the highest and the softest grade of bitumen was at ratio 2:0.5:7.5 $(\mathrm{H})$ containing the least amount of bitumen at 20 wt.\%. From Fig. 1, the closest penetration value is obtained from sample $\mathrm{G}$ by the difference of $18 \mathrm{~mm}$. This shows the recycled base oil and bitumen contained completely influence the grade of bitumen.

\section{Softening Point Test (ASTM D36)}

This softening value shows the temperature of the bitumen attaining a particular degree of softening point under the test specifications [19]. The softening point also indicates the grade of bitumen with a higher softening point is suitable for high temperature application. From Fig. 2, a lower content of bitumen gave a low softening point. It shows the sample ratio at 2:0.5:7.5 $(\mathrm{H})$ was the softest compared to others thus higher in temperature susceptibility. Out of all the samples, the sample by ratio 8:0.7:1.3 (A) attained the highest softening point meaning it is suitable in a warmer climate; it will not flow during service. This can be related by the least amount of recycled base oil since it was used as the medium to melt the polymer. From Fig. 2, modified bitumen $G$ has the closest softening value to the industrial grade with a difference of $0.9^{\circ} \mathrm{C}$.

\section{Thermogravimetric Analysis (TGA)}

Thermogravimetric analysis was carried out to determine a thermal characteristic of materials such as thermal stability, degradation temperature, and residue left at the end of the analysis. Table 4 shows TGA results obtained at a heating rate of $10^{\circ} \mathrm{C} / \mathrm{min}$ for pure bitumen and different ratios of bitumen, HDPE and recycled base oil. According to the result, pure bitumen has the highest

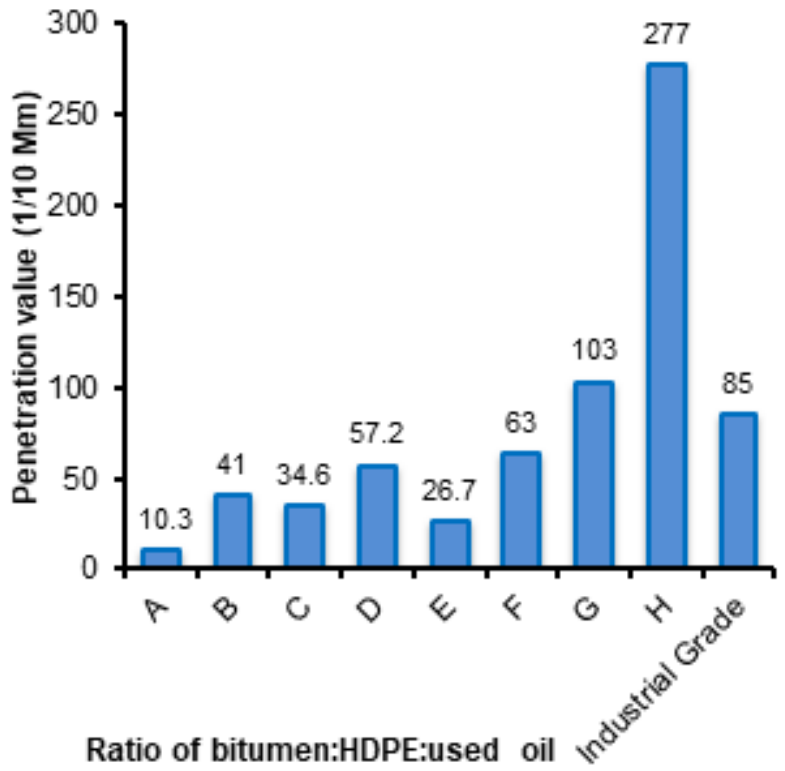

Fig 1. Penetration value against eight modified bitumen samples

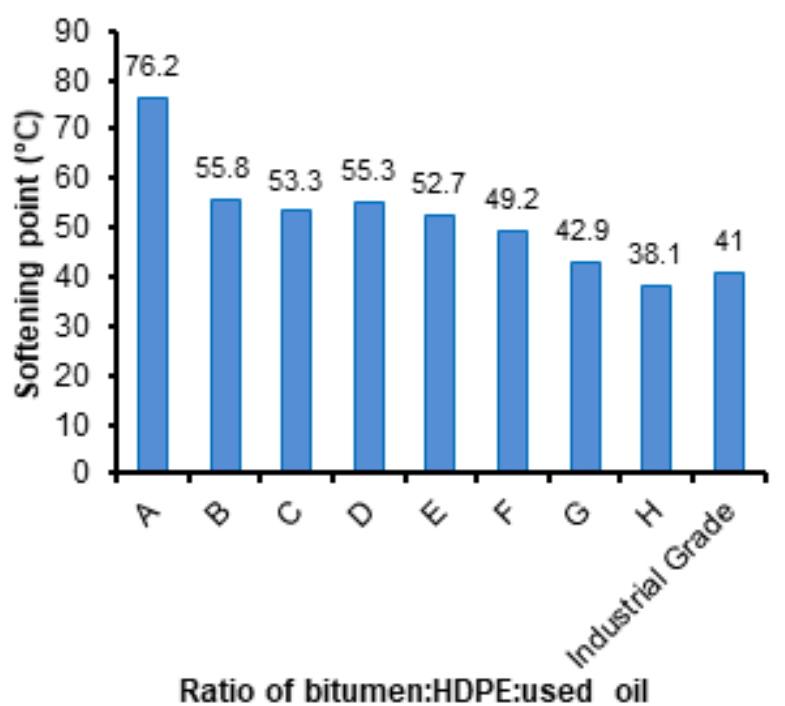

Fig 2. Graph of softening value against eight modified bitumen samples

thermal stability at $896.0{ }^{\circ} \mathrm{C}$ while modified bitumens are in the range of 895.8 to $893.3^{\circ} \mathrm{C}$. Also, the residue 
Table 3. Thermogravimetric analysis result

\begin{tabular}{|c|c|c|c|}
\hline No & Sample & $\begin{array}{l}\text { Weight change and temperature } \\
\text { subjected to sample }\end{array}$ & $\begin{array}{l}\text { Decompose } \\
\text { temperature }\left({ }^{\circ} \mathrm{C}\right)\end{array}$ \\
\hline 1 & A & $\begin{array}{l}40.9 \% \text { drop from } 100 \text { to } 350{ }^{\circ} \mathrm{C} \\
47.6 \% \text { drop from } 350 \text { to } 500{ }^{\circ} \mathrm{C} \\
8.9 \% \text { drop from } 500 \text { to } 700{ }^{\circ} \mathrm{C} \\
\text { Residue is } 0.27 \mathrm{mg}\end{array}$ & 895.8 \\
\hline 2 & B & $\begin{array}{l}23.6 \% \text { drop from } 100 \text { to } 380^{\circ} \mathrm{C} \\
47.6 \% \text { drop from } 400 \text { to } 520^{\circ} \mathrm{C} \\
\text { Residue is } 1.38 \mathrm{mg}\end{array}$ & 893.3 \\
\hline 3 & $\mathrm{C}$ & $\begin{array}{l}54.1 \% \text { drop from } 100 \text { to } 400{ }^{\circ} \mathrm{C} \\
37.0 \% \text { drop from } 400 \text { to } 480^{\circ} \mathrm{C} \\
\text { Residue is } 0.091 \mathrm{mg}\end{array}$ & 893.5 \\
\hline 4 & $\mathrm{D}$ & $\begin{array}{l}39.9 \% \text { drop from } 100 \text { to } 380^{\circ} \mathrm{C} \\
45.4 \% \text { drop from } 380 \text { to } 520^{\circ} \mathrm{C} \\
\text { Residue is } 0.606 \mathrm{mg}\end{array}$ & 893.6 \\
\hline 5 & $\mathrm{E}$ & $\begin{array}{l}53.9 \% \text { drop from } 100 \text { to } 400{ }^{\circ} \mathrm{C} \\
34.5 \% \text { drop from } 400 \text { to } 500^{\circ} \mathrm{C} \\
\text { Residue is } 0.090 \mathrm{mg}\end{array}$ & 894.2 \\
\hline 6 & $\mathrm{~F}$ & $\begin{array}{l}33.9 \% \text { drop from } 100 \text { to } 380^{\circ} \mathrm{C} \\
32.9 \% \text { drop from } 380 \text { to } 520^{\circ} \mathrm{C} \\
\text { Residue is } 0.201 \mathrm{mg}\end{array}$ & 894.2 \\
\hline 7 & G & $\begin{array}{l}79.8 \% \text { drop from } 100 \text { to } 400{ }^{\circ} \mathrm{C} \\
15.9 \% \text { drop from } 400 \text { to } 500{ }^{\circ} \mathrm{C} \\
\text { Residue is } 0.087 \mathrm{mg}\end{array}$ & 894.0 \\
\hline 8 & $\mathrm{H}$ & $\begin{array}{l}57.2 \% \text { drop from } 100 \text { to } 400{ }^{\circ} \mathrm{C} \\
30.0 \% \text { drop from } 400 \text { to } 520^{\circ} \mathrm{C} \\
\text { Residue is } 0.244 \mathrm{mg}\end{array}$ & 893.9 \\
\hline 9 & Industrial grade & $\begin{array}{l}32.29 \% \text { drop from } 100 \text { to } 350^{\circ} \mathrm{C} \\
38.05 \% \text { drop from } 350 \text { to } 500^{\circ} \mathrm{C} \\
29.36 \% \text { drop from } 500 \text { to } 600{ }^{\circ} \mathrm{C} \\
\text { Residue is } 0.013 \mathrm{mg}\end{array}$ & 896.03 \\
\hline
\end{tabular}

content of pure bitumen at the end of analysis is $0.013 \mathrm{mg}$ which is less than modified bitumen that has residue in the range of $1.38-0.087 \mathrm{mg}$. Lower residue content indicates material possess lower evaporation and higher stability against heat. The closest modified bitumen that has approximately the same final residue are the samples with a ratio (C) 6:0.7:3.8, (E) 4:0.7:5.3 and (G) 2:0.7:7.3. Farahani [20] reported the use of the polymer in bitumen to increase its stability against heat meaning polymer modified bitumen should have less residue content about $0.62 \mathrm{mg}$ lesser than pure bitumen. So in this case, the recycled base oil affects the result by at least $0.074 \mathrm{mg}$ higher than pure bitumen. Thus, it is shown that the degradation temperature and residue of all modified bitumen did not deviate much from pure bitumen.

\section{Characterization Formulation of Emulsified Modification Bitumen}

One ratio of modified bitumen among the eight total formulations was chosen based on the penetration and softening point value. The best ratio of formulation which resembles the industrial grade bitumen is 2:0.7:7.3 (bitumen:HDPE:used oil). This ratio was then emulsified by using three different emulsifiers and undergoes moisture content, rheology analysis and comparison with industrial grade bitumen emulsion in order to decide which formulation is the best.

\section{Moisture Content Test}

Moisture content is one of the analyses needed to be performed on the bitumen emulsion product as one 
of the quality control measures. Table 5 shows the result of moisture content in comparison with the industrial bitumen emulsion obtained from Selangor. There are three different emulsifiers used in this experiment. The only difference of BE 1, BE 2 and BE 3 was the emulsifier used to mix it with water. Initially, the same polymer modified bitumen with a penetration value of $103 \mathrm{~mm}$ was used during the emulsification process. So from Table 5, BE 1 has the lowest content of moisture whereas BE 3 contains the highest amount of moisture. The closest amount of moisture content with the industrial grade is BE 2 at approximately $51.12 \%$. The moisture content is related to its viscosity where low moisture content indicates a higher viscosity. In all applications, the viscosity of the emulsion is important, because too viscous emulsions will be less pumpable and too much fluid the emulsions may not form thick films especially in road applications [21].

\section{Rheology}

Fig. 3 shows isochronal plots of complex modulus $\left(G^{*}\right)$ versus temperature at $10 \mathrm{~Hz}$ loading application on samples of bitumen emulsion containing different ratios of polymer and recycled base oil. These samples are emulsified by using three different emulsifiers which are two anionic and one cationic emulsifier. It can be seen from Fig. 4 that amongst three bitumen emulsions, BE3 is much comparable to industrial grade bitumen emulsion which results in increased stiffness value. Normally at low service temperatures, $G^{*}$ value will have small increases causing the slope of the complex modulus isochrones to decrease, and at high service temperature, $G^{*}$ will be incrementally larger [4]. So by comparing both curves (BE3 and industrial grade bitumen emulsion), it shows BE3 is having some improvements in temperature susceptibility thus indicate it could perform better at average service temperatures while showing a shoulder at $100^{\circ} \mathrm{C}$.

Table 5. Moisture content value in bitumen emulsion (\%)

\begin{tabular}{lc}
\hline Sample & Moisture Content (\%) \\
\hline Industrial BE & 43.37 \\
BE 1 & 31.03 \\
BE 2 & 51.12 \\
BE 3 & 55.85 \\
\hline
\end{tabular}

Note: BE: Bitumen emulsion

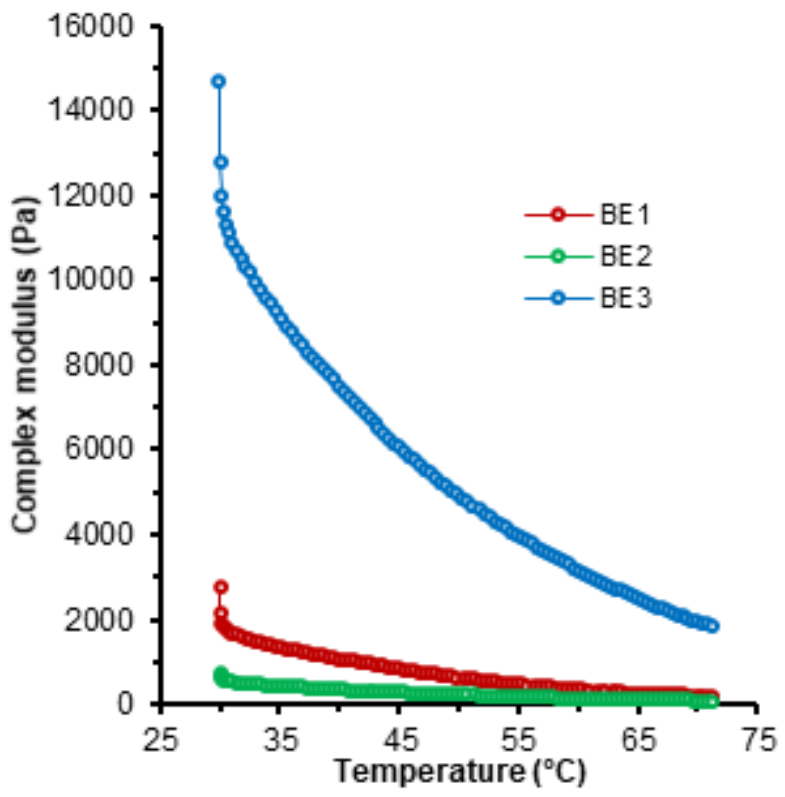

Fig 3. Graph of complex modulus (Pa) against temperature $\left({ }^{\circ} \mathrm{C}\right)$

\section{- CONCLUSION}

From several analyses done to the industrial wastes from bitumen conventional analysis on penetration and softening tests, it was found that modified bitumen formulation with a ratio of 2:0.7:7.3 resembles an industrial bitumen but with higher penetration value at $103 \mathrm{~mm}$ and softening point of $0.9^{\circ} \mathrm{C}$ higher than that of the industrial bitumen. It shows that the modified bitumen has a higher ability in terms of temperature susceptibility. The moisture content analysis done on the bitumen emulsion showed that the amount of moisture content in $\mathrm{BE} 2$ was $7.75 \%$ higher than the industrial bitumen emulsion. Higher moisture content results in an easier pumping during its application. From the TGA result, the recycled base oil in the formulation gave some effects to the thermal stability of the modified bitumen since it gave lesser residue content of approximately $0.62 \mathrm{mg}$ as polymer will yield higher stability against heat. In the rheology test, BE3 showed higher temperature susceptibility, indicating that it could perform better for its application. In short, emulsified modification bitumen was comparable and had almost similar characteristics with the industrial emulsion. 


\section{- ACKNOWLEDGMENTS}

The authors wish to express their gratitude and appreciation for the financial support from the Ministry of Higher Education (MOHE), Malaysia for the Fundamental Research Grant Scheme (FRGS KPT RDU160129, Reference Number: FRGS/1/2016/TK02/ UMP/03/2 entitled Rheological and Structural Characterization of Emulsified Modification Bitumen Synthesized from Industrial Wastes) and the Universiti Malaysia Pahang for the Internal Grant (RDU160324). The support from the Faculty of Chemical and Natural Resources Engineering and Universiti Malaysia Pahang, Malaysia are also acknowledged.

\section{- REFERENCES}

[1] McNally, T., 2011, Polymer Modified Bitumen: Properties and Characterization, Woodhead Publishing, Philadelphia, USA, 1.

[2] Asphalt Institute and Eurobitume, 2011, The Bitumen Industry - A Global Perspective: Production, Chemistry, Use, Specification and Occupational Exposure., Lexington, Kentucky, USA, 6.

[3] Arab, D., Kantzas, A., and Bryant, S.L., 2018, Nanoparticle stabilized oil in water emulsions, J. Pet. Sci. Eng., 163, 217-242.

[4] Khadivar, A., and Kavussi, A., 2013, Rheological characteristics of SBR and NR polymer modified bitumen emulsions at average pavement temperatures, Constr. Build. Mater., 47, 1099-1105.

[5] Global Market Insights, 2017, Bitumen emulsifiers market, https://www.gminsights.com, accessed on September 7, 2018.

[6] Kathirvale, S., Yunus, M.N.M., Sopian, K., and Samsuddin, A.H., 2004, Energy potential from municipal solid waste in Malaysia, Renewable Energy, 29 (4), 559-567.

[7] Department of Statistics Malaysia, 2016, Department of Statistics Malaysia Press Release Report on Survey of Manufacturing Industries 2015, https://www.dosm.gov.my/, accessed on February 2, 2017.

[8] Yaacob, H., Hainin, M.R., Aziz, M.M.A., Warid, N.M., Chang, F.L., Ismail, C.R., and Hassan N.A.,
2013, Bitumen emulsion in Malaysia-a conceptual, Jurnal Teknologi, 65 (3), 97-104.

[9] Carrera, V., Cuadri, A.A., García-Morales, M., and Partal, P., 2015, The development of polyurethane modified bitumen emulsions for cold mix applications, Mater. Struct., 48 (10), 3407-3414.

[10] Carrera, V., Partal, P., García-Morales, M., Gallegos, C., and Páez, A., 2009, Influence of bitumen colloidal nature on the design of isocyanate-based bituminous products with enhanced rheological properties, Ind. Eng. Chem. Res., 48 (18), 8464-8470.

[11] Cai, H.M., Wang, T., Zhang, J.Y., and Zhang, Y.Z, 2017, Preparation of an SBS latex-Modified bitumen emulsion and performance assessment, Pet. Sci. Technol., 28 (10), 987-996.

[12] Perdelli, F., Cristina, M.L., Sartini, M., Spagnolo, A.M., Dallera, M., Ottria, G., Lombardi, R., Grimaldi, M, and Orlando, P., 2006, Fungal contamination in hospital environmets, Infect. Control Hosp. Epidemiol., 27 (1), 44-47.

[13] Saadoun, I., Tayyar, I.A.A., and Elnasser, Z., 2008, Concentrations of airborne fungal contamination in the medical sugery operation theaters of different hospitals in northern Jordan, Jordan J. Biol. Sci., 1 (4), 181-184.

[14] Razali, M.N., Isa, S.N.E., Salehan, N.A.M, Musa, M., Aziz, M.A.A., Nour, A.H., and Yunus, R.M., 2018, Characterization of industrial wastes as raw materials for emulsified modified bitumen formulation, IOP Conf. Ser. Mater. Sci. Eng., 342, 012072.

[15] Piorek, S., 2004, Feasibility of Analysis and Screening of Plastics for Heavy Metals with Portable X-Ray Fluorescence Analyzer with Miniature X-Ray Tube, Global Plastics Environmental Conference 2004: GPEC 2004, Marriott Renaissance Center, Detroit, MI, February 18-19, 2004.

[16] Roads and Maritime Services (RMS), 2010, Guide to selection of polymer modified binder, http://www.rms.nsw.gov.au, accessed on September 7, 2018. 
[17] Munera, J.C., and Ossa, E.A., 2014, Polymer modified bitumen: Optimization and selection, Mater. Des., 62, 91-97.

[18] Razali, M.N., Aziz, M.A.A., Jamin, N.F.M., and Salehan, N.A.M, 2018, Modification of bitumen using polyacrylic wig waste, AIP Conf. Proc., 1930 (1), 020051.

[19] Mathew, T.V., and Rao, K.V.K., 2006, Introduction to Transportation Engineering, NPTEL Web Course,
Civil Engineering Department, Indian Institute of Technology Bombay, India.

[20] Farahani, H.Z., Palassi, M., and Galooyak, S.S, 2017, Thermal analysis of bitumen modified with LDPE and CR, Pet. Sci. Technol., 35 (15), 1570-1575.

[21] Lesueur, D, 2003, The rheological properties of bitumen emulsions. Part I-Theoretical relationships between efflux time and rheological behaviour, Road Mater. Pavement Des., 4 (2), 151-168. 